\title{
Preparo do Leito da Ferida antes do Tratamento Cirúrgico da Úlcera por Pressão em Indivíduos com Lesão Medular
}

\author{
Wound Bed Preparation Before Surgical Treatment of Pressure Ulcers in \\ Patients With Spinal Cord Injury
}

\author{
La Preparación Del Lecho de la Herida Antes Al Tratamiento Quirúrgico de \\ las Úlceras Por Presión en Personas Con Lesión de la Médula Espinal
}

\author{
Lisabel Tabari', Ivone Kamada
}

\begin{abstract}
*Dissertação apresentada ao Departamento de Enfermagem da Faculdade de Ciências da Saúde da Universidade de Brasília, como requisito parcial para obtenção do título de Mestre em Enfermagem, defendida em 29 de agosto de 2014.
\end{abstract}

\begin{abstract}
A lesão traumática da medula espinhal causa alterações neurológicas importantes, que colocam o indivíduo em risco de desenvolvimento da úlcera por pressão durante a vida. Diversos fatores estão envolvidos no surgimento e na cronicidade da ferida, entre eles os fisiológicos, microbiológicos, sociais, econômicos, educacionais e comportamentais. São importantes os estudos que descrevem os cuidados com a ferida, de forma a identificar fatores que interferem na sua cronicidade, no crescimento bacteriano e na formação do biofilme. Assim, este estudo buscou descrever os cuidados com as úlceras por pressão no período pré-operatório do tratamento cirúrgico, as mudanças microbiológicas e a presença do biofilme bacteriano, antes e após o uso da polihexanida e da terapia tópica, conforme protocolo institucional. O trabalho foi realizado de forma prospectiva, incluindo pacientes com diagnóstico de lesão traumática da medula espinhal internados em um hospital de reabilitação para tratamento cirúrgico de úlcera por pressão em estágio IV. Após aprovação do Comitê de Ética em Pesquisa da instituição, foram incluídos na amostra cinco pacientes adultos, com idade igual ou superior a 18 anos. Os dados foram coletados pela inspeção e mensuração das feridas, por cultura de material da lesão obtido por swab, irrigação-aspiração e biópsia. A maior parte dos pacientes era composta por homens, jovens, solteiros, negros, paraplégicos por projétil de arma de fogo, de baixa escolaridade, com baixa renda e sem emprego formal. A maior parte era independente para as atividades de vida diária; apresentava úlcera por pressão em região isquiática há mais de três anos; tinha cadeira de rodas inadequada; permanecia por longo período sentada; não realizava alívio de pressão com frequência; utilizava água e sabão para higiene das feridas, e soro fisiológico e óleo com ácidos graxos essenciais para os curativos; não fazia acompanhamento em serviços especializados e julgava o tratamento realizado inadequado. No ambiente hospitalar, as feridas foram limpas diariamente com solução de polihexanida, avaliadas e tratadas com ácidos graxos essenciais, alginato de cálcio e hidrogel. As análises da inspeção e mensuração e do registro fotográfico evidenciaram melhora das condições do leito da ferida após os cuidados realizados no pré-operatório. As análises microbiológicas do material coletado demonstraram que, após o tratamento tópico, houve redução do número de colônias de Pseudomonas aeruginosas e Staphylococcus aureus e aumento dos casos de Acinectobacter baumannii complex. A microscopia eletrônica de varredura demonstrou que todas as amostras mantinham a presença de biofilme, mesmo após o uso da polihexanida. Observou-se que existe uma dificuldade em controlar a carga microbiológica e eliminar o biofilme da úlcera por pressão em função de vários fatores que estão envolvidos na cronicidade da ferida em indivíduos com lesão medular. Novas investigações são necessárias para buscar evidências sobre os fatores que levam à cronicidade da ferida e aos efeitos da polihexanida na microbiologia das úlceras por pressão.
\end{abstract}

DESCRITORES: Traumatismos da medula espinhal. Cuidados de Enfermagem. Enfermagem perioperatória. Enfermagem prática. Úlcera por pressão. Microbiologia. Estomaterapia.

'Faculdade de Ciências da Saúde da Universidade de Brasília (UnB) - Brasília (DF), Brasil.

Endereço para correspondência: Lisabel Tabari - SMHS Qd 501 - Área Especial 01 - CEP:70335-901 - Brasília (DF), Brasil E-mail: lisabel@sarah.br Artigo recebido em: 14/05/2015 - Aceito para publicação em: 23/05/2016 